\title{
Nano-TiO $/ 2$ PEEK bioactive composite as a bone substitute material: in vitro and in vivo studies
}

This article was published in the following Dove Press journal:

International Journal of Nanomedicine

2 March 2012

Number of times this article has been viewed

\section{Xiaomian $\mathrm{Wu}^{\mathrm{I}}$ \\ Xiaochen Liu $^{2}$ \\ Jie $\mathrm{Wei}^{3}$ \\ Jian $\mathrm{Ma}^{4}$ \\ Feng Deng' \\ Shicheng Wei'}

'Research Center for Oral Diseases and Biomedical Science, College of Stomatology, Chongqing Medical University, Chongqing, ${ }^{2}$ Center for Biomedical Materials and Tissue Engineering, Academy for Advanced Interdisciplinary Studies, Peking University, Beijing, ${ }^{3}$ Key Laboratory for Ultrafine Materials of Ministry of Education, East China University of Science and Technology, Shanghai, ${ }^{4}$ Hospital of Stomatology, Tongji

University, Shanghai, People's Republic of China

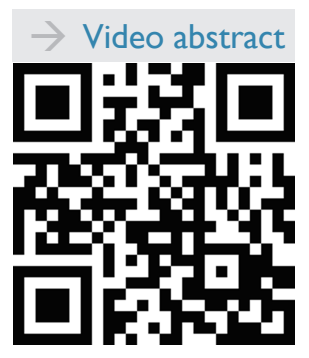

Correspondence: Feng Deng; Shicheng Wei Research Center for Oral Diseases and Biomedical Science, College of Stomatology, Chongqing Medical University, 40I I47, Chongqing,

People's Republic of China

Tel +862388860006

Fax +86 2388860222

Email deng63@263.net (F Deng);

weishicheng99@I63.com (S Wei)
Background: Compared with titanium (Ti) and other metal implant materials, poly(ether-ether ketone) (PEEK) shows outstanding biomechanical properties. A number of studies have also reported attractive bioactivity for nano- $\mathrm{TiO}_{2}\left(\mathrm{n}-\mathrm{TiO}_{2}\right)$.

Methods: In this study, $\mathrm{n}-\mathrm{TiO}_{2} / \mathrm{PEEK}$ nanocomposites were prepared, taking advantage of the unique properties of both PEEK polymer and $n-\mathrm{TiO}_{2}$. The in vitro and in vivo bioactivity of these nanocomposites was assessed against a PEEK polymer control. The effect of surface morphology or roughness on the bioactivity of the $n-\mathrm{TiO}_{2} / \mathrm{PEEK}$ nanocomposites was also studied. $\mathrm{n}-\mathrm{TiO}_{2} / \mathrm{PEEK}$ was successfully fabricated and cut into disks for physical and chemical characterization and in vitro studies, and prepared as cylindrical implants for in vivo studies. Their presence on the surface and dispersion in the composites was observed and analyzed by scanning and transmission electron microscopy and X-ray photoelectron spectroscopy.

Results: Bioactivity evaluation of the nanocomposites revealed that pseudopods of osteoblasts preferred to anchor at areas where $\mathrm{n}-\mathrm{TiO}_{2}$ was present on the surface. In a cell attachment test, smooth PEEK showed the lowest optical density value $(0.56 \pm 0.07)$ while rough $n-\mathrm{TiO}_{2} / \mathrm{PEEK}$ exhibited the highest optical density value $(1.21 \pm 0.34, P<0.05)$. In in vivo studies, the percent bone volume value of $\mathrm{n}-\mathrm{TiO}_{2} / \mathrm{PEEK}$ was approximately twice as large as that of PEEK $(P<0.05)$. Vivid three-dimensional and histologic images of the newly generated bone on the implants further supported our test results.

Conclusion: Our study demonstrates that $\mathrm{n}-\mathrm{TiO}_{2}$ significantly improves the bioactivity of PEEK, especially if it has a rough composite surface. $\mathrm{A} n-\mathrm{TiO}_{2} / \mathrm{PEEK}$ composite with a rough surface could be a novel alternative implant material for orthopedic and dental applications.

Keywords: polyether-ether-ketone, bioactivity, $\mathrm{TiO}_{2}$, nanocomposite, polymer, implant

\section{Introduction}

Implants of titanium (Ti) and Ti alloy have been widely utilized as orthopedic and dental materials. ${ }^{1-3}$ However, a number of issues associated with metal implants, including Ti and Ti alloys, have been reported in long-term clinical studies. ${ }^{4-6}$ Two major issues are stress shielding and local inflammation. Stress shielding is due to stress mismatch between the metal implant material and surrounding bone tissue. Local inflammation is caused by metal implant debris from wear and corrosion. These two issues are considered to be the major causes of bone loss and implant failure. ${ }^{5,6}$

Poly(ether-ether-ketone) (PEEK), on the other hand, is considered to be one of the best choices to resolve stress shielding issues due to its outstanding biocompatibility and biomechanical properties, ${ }^{6}$ such as a low modulus, compared with a metal implant 
and high strength compared with other polymers. However, the bioinert nature of PEEK is not conducive to fast bone cell attachment. ${ }^{7-9}$ There is a need to improve its bioactivity for orthopedic and dental applications.

The exceptional anticorrosive and biocompatibility properties of $\mathrm{Ti}$ and $\mathrm{Ti}$ alloy are due to a protective oxide layer (mainly $\mathrm{TiO}_{2}$ ) which forms rapidly on the Ti surface when it is exposed to the atmosphere. ${ }^{10,11}$ It was reported that calcium-phosphorus mineralization tended to occur on microgrooved $\mathrm{TiO}_{2}$ surfaces in the initial days. ${ }^{12}$ Using an arc ion plating technique, a thin microsized $\mathrm{TiO}_{2}$ film was deposited onto a PEEK substrate, which promoted significant adhesion, proliferation, and differentiation of osteoblast cells, compared with a PEEK substrate without $\mathrm{TiO}_{2}$ coating. ${ }^{13}$

It is believed that $\mathrm{TiO}_{2}$ nanoparticles have higher bioactivity than conventional (micron) particle sizes. When exposed to nanophase $\mathrm{TiO}_{2}$ particles, osteoblasts and chondrocytes show a well spread morphology and increased proliferation compared with cells exposed to particles of conventional size. ${ }^{14}$ Compared with a micropit titanium surface, a micropit titanium surface with nanonodules promotes significant differentiation and proliferation of osteoblasts in in vitro studies. ${ }^{15}$ Further, on biomechanical testing of implants, the strength of bone-titanium integration is three times greater for implants with micropits and $300 \mathrm{~nm}$ nanonodules than those with micropits alone. $\mathrm{A} \mathrm{TiO}_{2}$ nanotube surface significantly accelerates osteoblast adhesion and shows strong bonding with bone. ${ }^{16} \mathrm{TiO}_{2}$ nanonetwork formation on the Ti surfaces significantly improves human bone marrow mesenchymal stem cell growth in vitro and in vivo. ${ }^{10}$ Therefore, various kinds of $\mathrm{n}-\mathrm{TiO}_{2}$ enhanced polymers have been fabricated for biomaterial applications such as g- $\mathrm{TiO}_{2} /$ poly-L-lactide acid nanocomposites ${ }^{17}$ and poly(lactic-coglycolic acid) $/ \mathrm{TiO}_{2}$ nanoparticle-filled composites. ${ }^{18}$ It is reported that poly (D, L lactic acid) film containing $20 \mathrm{wt} \%$ $\mathrm{TiO}_{2}$ could improve the formation of hydroxyapatite (HA) after 21 days' exposure to simulated body fluid and increase the relative metabolic activity of MG-63 cells after seven days of incubation. ${ }^{19}$

All the aforementioned studies suggest that the excellent biocompatibility and bioactivity of $\mathrm{n}-\mathrm{TiO}_{2}$ composites is due mainly to the favorable bioactivity of $\mathrm{TiO}_{2}$ nanoparticles in composites and the surface morphology of the $\mathrm{TiO}_{2}$ layer. The aim of this study was to utilize $n-\mathrm{TiO}_{2}$ to improve the bioactivity of PEEK and to investigate the bioactivity of $\mathrm{n}-\mathrm{TiO}_{2} / \mathrm{PEEK}$ composites both in vitro and in vivo. Specific attention was also paid to the biologic effect of $n-\mathrm{TiO}_{2}$ on the composite surface as well as the biologic effect of the surface roughness of the $\mathrm{n}-\mathrm{TiO}_{2} / \mathrm{PEEK}$ composite.

\section{Materials and methods}

\section{Sample preparation}

PEEK powder was obtained from Victrex (Lancashire, $\mathrm{UK}$ ) and the $\mathrm{TiO}_{2}$ nanoparticle/PEEK composite (n-TiO/ PEEK) was fabricated by powder mixing and compression molding methods ${ }^{20}$ in the Key Laboratory for Ultrafine Material of Ministry of Education, School of Materials Science and Engineering, East China University of Science and Technology, Shanghai. In this study, the amount of $\mathrm{n}-\mathrm{TiO}_{2}$ in the $\mathrm{n}-\mathrm{TiO}_{2} / \mathrm{PEEK}$ composite was $40 \mathrm{wt} \%$ (bending modulus $3.8 \mathrm{GPa}$; bending strength $93 \mathrm{MPa}$ ), because a value greater than this would have interfered with the mechanical properties of the composite (data not shown).

In brief, appropriate amounts of $\mathrm{n}-\mathrm{TiO}_{2}$ and $\mathrm{PEEK}$ powder were codispersed using an electronic blender in alcohol to obtain a homogeneous powder mixture. When well dispersed, the mixture was dried in a forced convection oven at $90^{\circ} \mathrm{C}$ to remove the excess alcohol. The resulting powder mixture was placed in two specially designed molds, ie, disks $(\Phi 15 \times 2 \mathrm{~mm})$ for physical and chemical characterization and in vitro testing and cylindrical implants $(\Phi 4 \times 7 \mathrm{~mm})$ for in vivo testing. The moulds and powder mixtures were preheated to $150^{\circ} \mathrm{C}$ under a load of $35 \mathrm{MPa}$, and the temperature was increased to $400^{\circ} \mathrm{C}$ under a load of $15 \mathrm{MPa}$. After reaching the target temperature, the temperature and pressure were held for 10 minutes, and then the heater was turned off and the pressure was released after 10 minutes. The die and the samples were air cooled to $150^{\circ} \mathrm{C}$ and the samples were removed from the molds.

Disk samples of $\mathrm{n}-\mathrm{TiO}_{2} / \mathrm{PEEK}$ composite were polished to 2000 and tested by a mechanical profilomoter (Dektek8 stylus profiler; Veeco, Plainview, NY). Disk samples with roughness average ( $\mathrm{Ra}$ ) below $0.1 \mu \mathrm{m}$ were collected and considered as smooth groups. Some disk samples for the smooth groups were blasted by $\mathrm{TiO}_{2}$ particles and tested by profilomoter, and the disks with $\mathrm{Ra} 1.0-2.2 \mu \mathrm{m}$ were collected and considered to be the rough groups. Unfilled PEEK samples were cut into the same shapes and prepared according to the same process as the control groups. Surface roughness is thought to be beneficial for the bioactivity of implants, and most implants utilized in the clinic are blasted. Therefore, all implant samples in this study were blasted for the animal experiments. In order to remove any potential free $\mathrm{TiO}_{2}$ nanoparticles, all samples were cleaned with deionized water using an ultrasonic cleaner for 8 hours. The deionized water was changed every 20 minutes during the ultrasonic cleaning process. 


\section{Characterization}

TEM analysis of $n-T_{2}$ /PEEK composite

In order to characterize the $\mathrm{n}-\mathrm{TiO}_{2}$ dispersion of the $\mathrm{n}-\mathrm{TiO}_{2} /$ PEEK composite, thin foil transmission electron microscope (TEM) specimens were prepared by microtome with a diamond knife and imaged using a FEI Tecnai F20 TEM (Philips Electron Optics, Eindhoven, the Netherlands) at $200 \mathrm{KeV}$.

\section{SEM analysis of $n-\mathrm{TiO}_{2} / \mathrm{PEEK}$ composites}

After treatment, the samples were sputter-coated with gold by a coating device (550X; Quorum, Hampshire, UK), and the surface morphology of the samples was observed using scanning electron microscopy (SEM; S-4800, Hitachi, Tokyo, Japan).

\section{Composite surface analysis by XPS}

An X-ray photoelectron spectroscopy (XPS; Axis-Ultra, Kratos Analytical, Manchester, UK) study was carried out for surface chemical analysis using monochromatic $\mathrm{AL} \mathrm{K \alpha}$ radiation $(225 \mathrm{~W}, 15 \mathrm{~mA}, 15 \mathrm{kV})$ and low-energy electron flooding for charge compensation. Binding energies were calibrated using a $\mathrm{C} 1 \mathrm{~s}$ hydrocarbon peak at $284.8 \mathrm{eV}$ to compensate for surface charge effects. For manipulation and curve-fitting, the data were converted into a VAMAS file format and imported into CasaXPS software package.

\section{Cytocompatibility in vitro}

Cell attachment, cytotoxicity, cell morphology, and flow cytometric analysis were evaluated using MG-63 osteoblast cells obtained from the American Type Culture Collection. MG-63 was cultured at $37^{\circ} \mathrm{C}$ in a humidified, $5 \% \mathrm{CO}_{2} / 95 \%$ air incubator, in modified Eagle's medium with $10 \%$ fetal bovine serum (Hyclone, Logan, UT), $100 \mathrm{U} / \mathrm{mL}$ penicillin (Amresco, Cleveland, $\mathrm{OH}$ ), and $0.1 \mathrm{mg} / \mathrm{mL}$ streptomycin (Amresco). Prior to in vitro testing, the samples were sterilized using gamma radiation at a total dose of $25 \mathrm{KG} \gamma$. The MG-63 cells were seeded at a density of $1 \times 10^{5}$ cells in each well of 24-well plates for cell attachment testing and at a density of $1.05 \times 10^{4}$ cells $/ \mathrm{cm}^{2}$ for the other in vitro tests $(n=6)$. The culture period for cell attachment was 4 hours. There were three culture periods $(3,7$, and 14 days) for cytotoxicity, cell morphology, and flow cytometric analysis.

\section{Cell attachment}

After culture on samples for 4 hours, the culture medium was removed and the specimen was rinsed with phosphate-buffered saline three times in order to remove the unattached cells.
Cell viability of the adherent cells was measured by adding $1 \mathrm{~mL} /$ well culture medium containing $100 \mu \mathrm{L} /$ well Cell Proliferation Reagent WST-1 (Roche Diagnostics, Mannheim, Germany). Adherent cells were incubated on samples at $37^{\circ} \mathrm{C}$ for another 4 hours, and $100 \mu \mathrm{L}$ of culture medium was then transferred into each well of a 96-well plate from each corresponding well of a 24-well plate. Ultraviolet absorbance was measured using an enzyme-linked immunosorbent assay reader at $450 \mathrm{~nm}$ with the reference wavelength at $630 \mathrm{~nm}$.

\section{Cytotoxicity}

After different culture periods (3, 7, and 14 days) cytotoxicity was evaluated using the WST-1 test on the rough and smooth surfaces of PEEK and n-TiO $/ 2$ PEEK disks. At fixed detection times, the culture medium was replaced with a new $1 \mathrm{~mL} /$ well culture medium containing WST-1 reagent at $100 \mu \mathrm{L} /$ well. Cells were cultured at $37^{\circ} \mathrm{C}$ for another 4 hours and ultraviolet absorbance was measured as described above. The relative growth rate was calculated.

\section{Cell morphology}

To observe the cell morphology, the samples were washed with phosphate-buffered saline at fixed experimental times $(3,7$, and 14 days), and cells on the various materials were fixed with $4 \%$ glutaraldehyde in phosphate-buffered saline (pH 7.3) for 30 minutes and dehydrated in a graded series of alcohols. Prior to SEM observation, the cells on the samples were sputter-coated and observed as described above.

\section{Flow cytometric analysis}

To investigate the cell cycle of MG-63 osteoblasts further, the cells were stained using propidium iodide (Invitrogen, Carlsbad, CA) and analyzed by flow cytometry (BD FACSCalibur; Becton-Dickson, Franklin Lakes, NJ). In summary, the cells were initially cultured on samples for 3, 7, and 14 days. They were then collected, washed with phosphate-buffered saline $\left(4^{\circ} \mathrm{C}\right)$, and resuspended in phosphate-buffered saline. Next, the cells were fixed in $75 \%$ ethanol and kept in ethanol at $-20^{\circ} \mathrm{C}$ for 16 hours. Finally, they were collected and washed again, and resuspended in $1 \mathrm{~mL}$ RNase $\mathrm{A}(1 \mu \mathrm{g} / \mathrm{mL})$ at room temperature for 30 minutes. The sample cells were pelleted by centrifugation, propidium iodide (Invitrogen) was added, and the cells were incubated for 15 minutes at room temperature, collected, and suspended once again in $1 \mathrm{~mL}$ Tris- $\mathrm{HCl}$ buffer ( $\mathrm{pH} 7.4)$, then analyzed by flow cytometry. 


\section{Biocompatibility in vivo}

Surgery process

Surgical implantation was performed on three beagle dogs aged 1.5 years and weighing $11.4 \pm 2.1 \mathrm{~kg}$ (mean \pm standard deviation). All procedures were conducted according to the ethical principles of the Peking University Institutional Animal Care and Use Committee. The sample implants were sterilized prior to surgery as described above for in vitro testing. General anesthesia was achieved using an intravenous injection of $1 \%$ pentobarbital $80 \mathrm{mg} / \mathrm{kg}$. For every composite sample, two cylindrical implants were placed on each animal on the medial surface of each tibia in the proximal diaphyseal region. For each group, ie, PEEK and $\mathrm{n}-\mathrm{TiO}_{2} / \mathrm{PEEK}$, there were six cylindrical implants placed. After surgery, three fluorochromes (Sigma, St Louis, MO), ie, calcein $(100 \mathrm{mg} / \mathrm{kg})$, calcein blue $(100 \mathrm{mg} / \mathrm{kg})$, and tetracycline $(100 \mathrm{mg} / \mathrm{kg})$ were administered to assess the osteogenic activity at weeks 1,2 , and 4 , respectively. The dogs were sacrificed 4 weeks after surgery by an intracardiac injection of $10 \%$ kalium chloratum $(0.5 \mathrm{~mL} / \mathrm{kg})$. The tibias were promptly fixed in $10 \%$ formalin and dehydrated in a graded series of alcohols.

\section{Microcomputed tomography analysis}

A scanner (1076, Skyscan) was utilized to evaluate all the tibias containing the implant at $40 \mathrm{kV}$ (X-ray source voltage), $200 \mu \mathrm{A}$ (beam current), $900 \mathrm{msec}$ (exposure time), $9 \mu \mathrm{m}$ (resolution), $0.8^{\circ}$ (rotation step), and $180^{\circ}$ (rotation angle). Using the CTan software package (Skyscan), percent bone volume was calculated choosing a serial polygonal region of interest in 100 slices with approximately $1 \mathrm{~mm}$ bonding to an implant, which represented the regenerated bone in the marrow only. Radiographs were also synthesized by the CTvol software package (Skyscan) to reconstruct three-dimensional regenerated bone of $0.5 \mathrm{~mm}$ width in the marrow bonding to the implants.

\section{Histologic analysis}

Following microcomputed tomographic analysis, ultrathin sections were obtained for histologic detection. In brief, the tibias were embedded in methyl methacrylate resin and sectioned after polymerization with a microtome (SP1600; Leica, Wetzlar, Germany) along the longitudinal axis of the cylindrical implants. The tissue sections were ground to a thickness of $30 \mu \mathrm{m}$ and detected using confocal laser scanning microscopy (LSM710 NLO; Zeiss, Oberkochen, Germany).

\section{Statistical analysis}

Data are presented as the mean \pm standard deviation $(n=6)$. Analysis of variance was utilized for calculation of the significance level of the data, and $P \leq 0.05$ was accepted as indicating statistical significance. All statistical analyses were carried out using OriginPro 8 SR3 software (OriginLab Corporation, Northampton, MA).

\section{Results}

\section{Characterization of materials} TEM analysis of $n-\mathrm{TiO}_{2} / \mathrm{PEEK}$ composite

Particle size and size distribution as well as dispersion play critical roles in the mechanical performance of nanocomposites as well as their biocompatibility and bioactivity. TEM imaging of our $\mathrm{n}-\mathrm{TiO}_{2} / \mathrm{PEEK}$ nanocomposite also showed relatively uniform dispersion of $\mathrm{n}-\mathrm{TiO}_{2}$ in PEEK (Figure 1).

\section{SEM analysis of $n-\mathrm{TiO}_{2} / \mathrm{PEEK}$ composite}

In order to understand the effect of implant surface morphology on cell culture and other biologic responses of PEEK with and without $\mathrm{n}-\mathrm{TiO}_{2}$, SEM analysis was carried out on the smooth and rough surfaces of pure $\mathrm{PEEK}$ and the $\mathrm{n}-\mathrm{TiO}_{2} / \mathrm{PEEK}$ composite. n- $-\mathrm{TiO}_{2}$ particles were visualized on the smooth $\mathrm{n}-\mathrm{TiO}_{2} /$ PEEK surface (Figure 2). A dramatic difference in surface morphology/tomography was observed between the smooth and rough sample surface prepared for bioactivity evaluation.

\section{Composite surface analysis by XPS}

As discussed earlier, distribution of $\mathrm{n}-\mathrm{TiO}_{2}$ in the composite, particularly on the surface, has a significant impact on

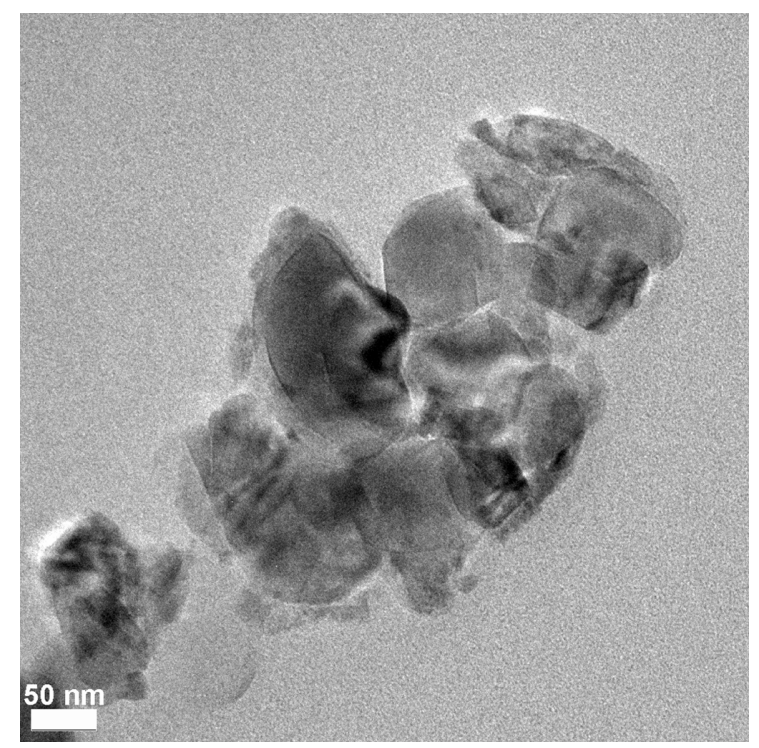

Figure I Transmission electron microscopy images of $\mathrm{n}-\mathrm{TiO}_{2}$ in $\mathrm{TiO}_{2} /$ poly(etherether-ketone) composite.

Note: Bar, $50 \mathrm{~nm}$. 

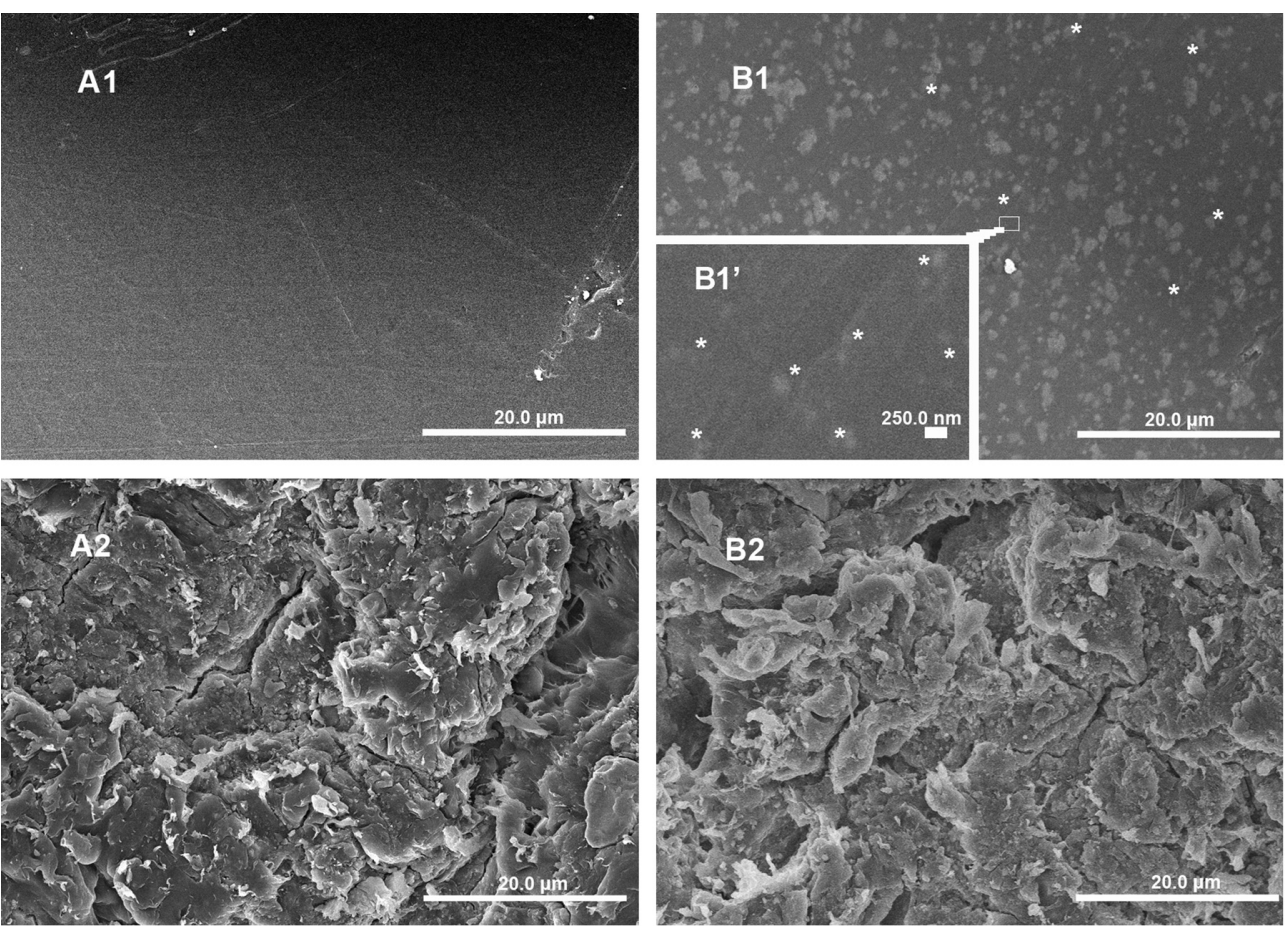

Figure 2 Scanning electron microscopy images of PEEK and n-TiO $/ 2$ PEEK before and after blasted treatment. (AI) Smooth PEEK, (A2) rough PEEK, (BI) smooth n-TiO ${ }_{2}$ $\mathrm{PEEK}$, and (B2) rough $\mathrm{n}-\mathrm{TiO}_{2} / \mathrm{PEEK}$.

Notes: ${ }^{n} \mathrm{n}-\mathrm{TiO}_{2}$ particles exposed to the surface of smooth $\mathrm{n}-\mathrm{TiO}_{2} / \mathrm{PEEK}$. (AI, A2, BI, and B2 bars, $20.0 \mu \mathrm{m}$; BI bar, $250.0 \mathrm{~nm}$ ).

Abbreviation: PEEK, poly(ether-ether-ketone).

composite tomography as well as bioactivity. XPS analysis demonstrated the presence of $\mathrm{Ti}$ on the surface of the $\mathrm{n}-\mathrm{TiO}_{2} / \mathrm{PEEK}$ composite (Figure 3 ), indicating the presence of $\mathrm{n}-\mathrm{TiO}_{2}$ on the surface.

\section{Cytocompatibility in vitro}

\section{Cell attachment}

Cell attachment was measured by WST-1 testing after 4 hours of culture of the various samples, and the results are shown in Figure 4. It is interesting to note that smooth PEEK showed the lowest optical density value $(0.56 \pm 0.07)$ among the groups $(P<0.05)$, while the rough $\mathrm{n}-\mathrm{TiO}_{2} / \mathrm{PEEK}$ group had a significantly higher optical density value $(1.21 \pm 0.34, P<0.05)$, indicating better cell attachment compared with the other groups. The study suggests the presence of $\mathrm{n}-\mathrm{TiO}_{2}$ in the composites, especially those with a rough surface, with marked attachment of cells to the implant surfaces.
A

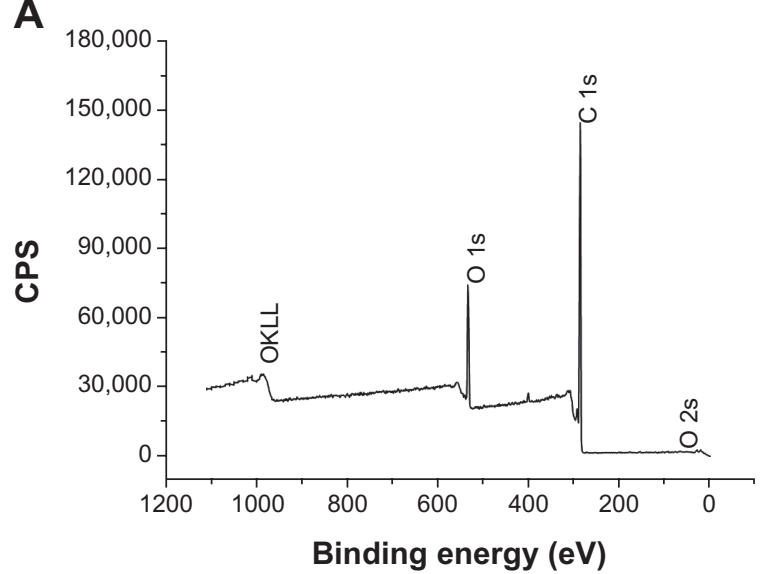

B

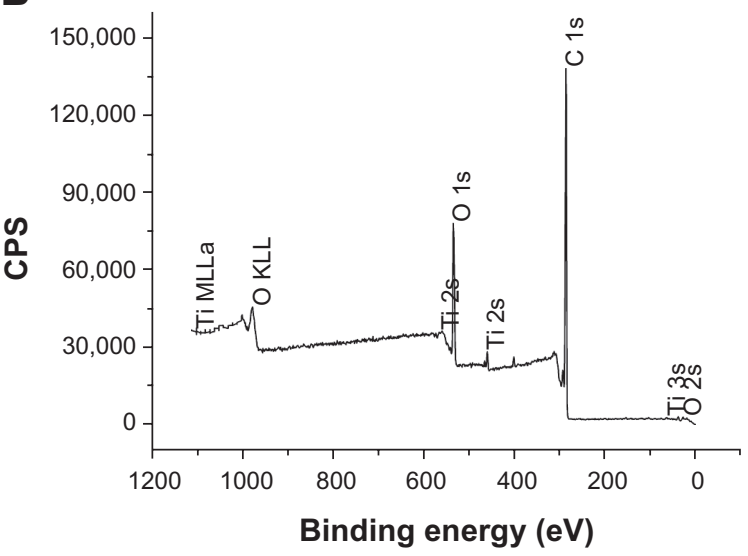

Figure 3 X-ray photoelectron spectroscopy of PEEK (A) and n-TiO /PEEK composite (B). Abbreviation: PEEK, poly(ether-ether-ketone). 


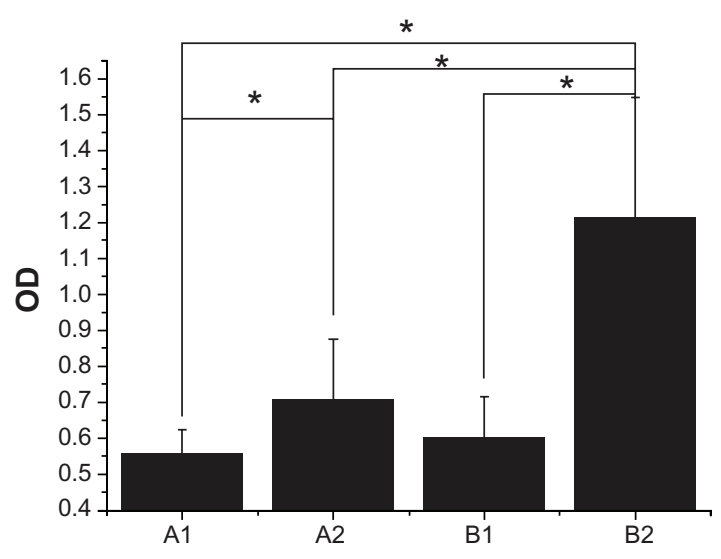

Figure 4 Cell attachment on PEEK and $n-T_{i O} /$ PEEK before and after blasted treatment. (AI) Smooth PEEK, (A2) rough PEEK, (BI) smooth n-TiO/2PEEK, and (B2) rough $\mathrm{n}-\mathrm{TiO}_{2} / \mathrm{PEEK}$

Note: $* P<0.05$.

Abbreviations: OD, optical density; PEEK, poly(ether-ether-ketone).

\section{Cytotoxicity}

The cytotoxicity of the various materials with smooth or rough surfaces was evaluated in terms of cell proliferation and viability at 3,7 , and 14 days. The relative growth rate in the four groups was more than $80 \%$ with cytotoxicity grade 1 , suggesting a lack of severe cytotoxicity in both the short term ( 3 days) and long term (7 and 14 days, Figure 5). The smooth $\mathrm{n}-\mathrm{TiO}_{2} / \mathrm{PEEK}$ group showed significantly higher $(P<0.05)$ cell proliferation and viability in the short term (3 days), compared with rough PEEK. During the short culture period (3 days), the smooth PEEK showed higher cell proliferation and viability $(P<0.05)$ than the rough $\mathrm{n}-\mathrm{TiO}_{2} / \mathrm{PEEK}$ group.

\section{Cell morphology}

In general, cells in the rough groups seemed to spread more efficiently, with numerous pseudopods (Figure 6), while cells

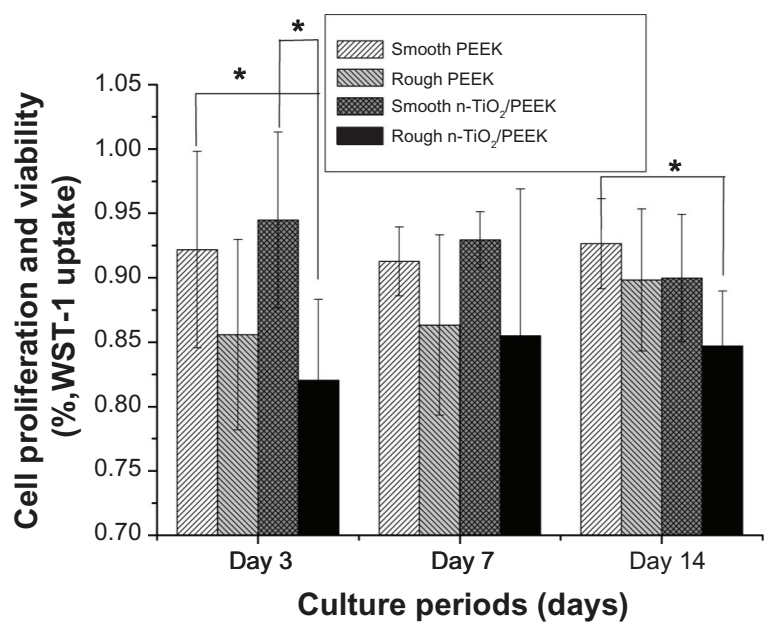

Figure 5 Cytotoxicity of the samples, smooth PEEK, rough PEEK, smooth $\mathrm{n}-\mathrm{TiO}_{2} /$ PEEK and rough $n-\mathrm{TiO}_{2} / \mathrm{PEEK}$, after 3,7 , and 14 days as measured by WST-I assay. Note: $* P<0.05$.

Abbreviation: PEEK, poly(ether-ether-ketone). on the smooth $\mathrm{n}-\mathrm{TiO}_{2} / \mathrm{PEEK}$ exhibited better spreading than the smooth PEEK groups. Pseudopods seemed to prefer to anchor at the areas where $n-\mathrm{TiO}_{2}$ was exposed. After longterm culture ( 7 and 14 days), no significant difference could be found among the groups.

\section{Flow cytometric analysis}

The cell cycle of the MG-63 cultures on the samples was further evaluated by measuring the DNA content of nuclei labeled with propidium iodide, and different cytodieresis phases (G0G1: pre-DNA synthesis of resting, S: DNA synthesis phase, G2M: post-DNA synthesis and mitosis) were analyzed. Figure 7 shows the total percentage of osteoblast MG-63 cells in the S and G2M phases for the four groups after the various culture periods ( 3,7 , and 14 days). For the short-term culture period ( 3 days), smooth $n-\mathrm{TiO}_{2} / \mathrm{PEEK}$ showed a larger percentage of cells in the $\mathrm{S}$ and $\mathrm{G} 2 \mathrm{M}$ phases compared with the rough group $(P<0.05)$, with no significant difference found in the other groups. For the long-term culture periods (7 and 14 days), although there was no significant difference found between rough PEEK and rough $\mathrm{n}-\mathrm{TiO}_{2} / \mathrm{PEEK}$, these two groups showed a larger percentage than the other groups $(P<0.05)$.

\section{Biocompatibility in vivo}

\section{Microcomputed tomography}

Microcomputed tomography makes it possible to calculate not only the new bone bonding to the implants in terms of percent of bone volume/tissue volume but also to reconstruct three-dimensional images. As shown in Figure 8, the bone volume/tissue volume of $\mathrm{n}-\mathrm{TiO}_{2} / \mathrm{PEEK}$ was about twice as large as that of PEEK $(P<0.05)$. These results could be seen clearly in the three-dimensional reconstructions (Figure 9).

\section{Histologic analysis}

Fluorochrome bone marker labels (calcein, calcein blue, and tetracycline) were clearly observed for bone tissue bonding to the cylindrical implants. More bone deposition and remodeling was seen around the $n-\mathrm{TiO}_{2} / \mathrm{PEEK}$ implants (Figure 10), suggesting a greater degree of bone regeneration than around the pure PEEK implants.

\section{Discussion}

While PEEK has exceptional biomechanical properties, there is a need to improve further its bioactivity for dental and orthopedic applications. The purpose of this study was to evaluate the in vitro and in vivo bioactivity of $n-\mathrm{TiO}_{2} / \mathrm{PEEK}$ with different surface morphologies. n- $\mathrm{TiO}_{2} / \mathrm{PEEK}$ composites were 

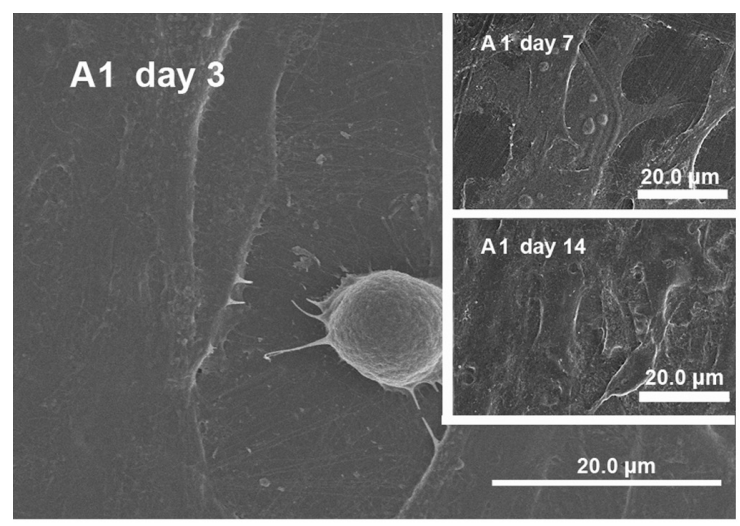

$20.0 \mu \mathrm{m}$

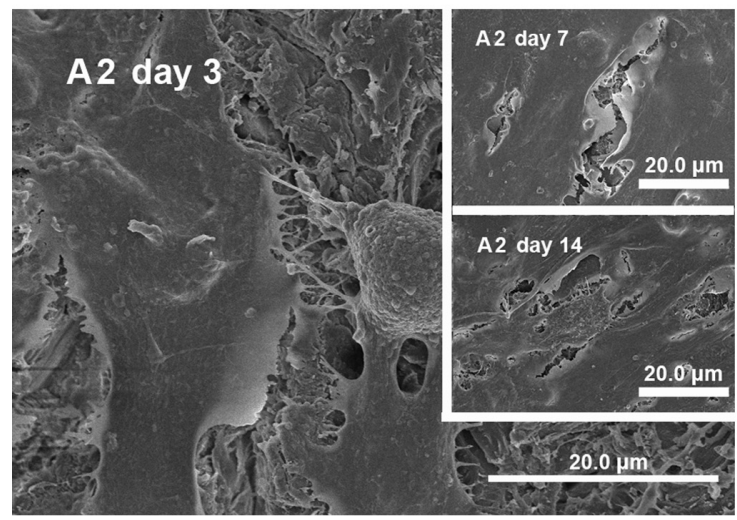

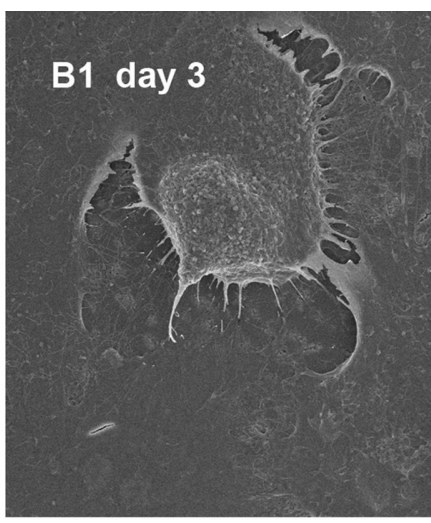
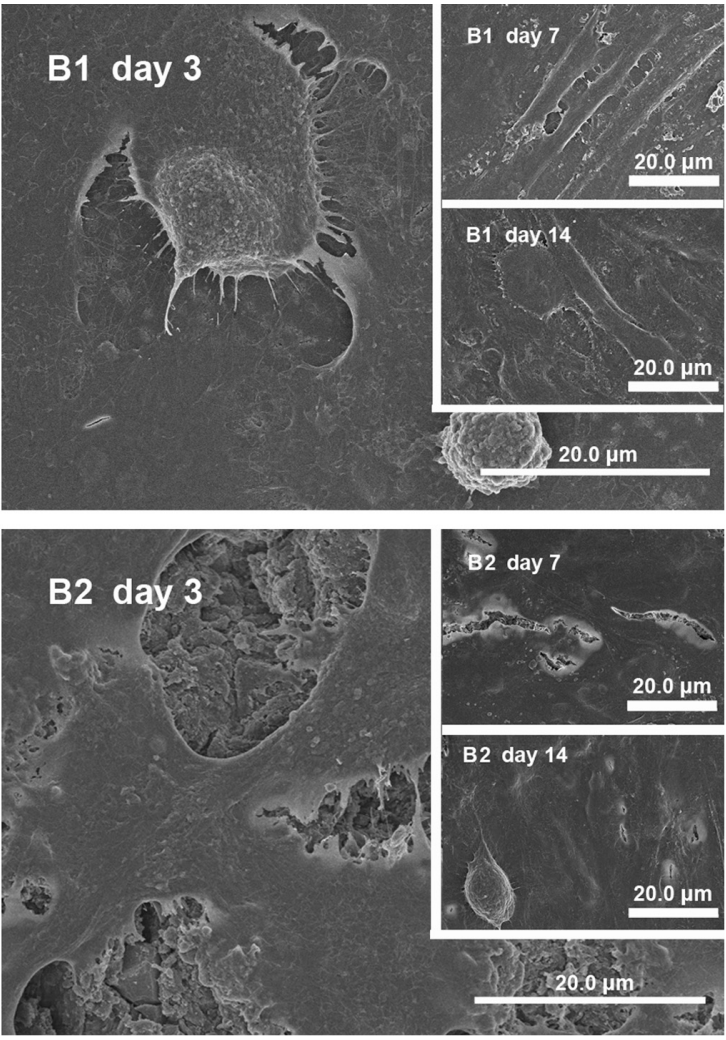

Figure 6 Cell morphology. (AI), (A2), (BI), and (B2) MG-63 cells cultured on disks of smooth PEEK, rough PEEK, smooth n-TiO $/ 2$ PEEK and rough n-TiO $/ 2$ PEEK for 3 days (AI, A2, BI and B2), 7 days (AI, A2, B I and B2) and I4 days (AI, A2, B I and B2), respectively.

Note: Bar $20.0 \mu \mathrm{m}$.

Abbreviation: PEEK, poly(ether-ether-ketone).

successfully fabricated. They did not cause severe cytotoxicity and there was no significant difference in nuclear DNA content compared with the other two materials. It was found that $\mathrm{n}-\mathrm{TiO}_{2}$ significantly improved osteoblast cell attachment, and cells on $\mathrm{n}-\mathrm{TiO}_{2} / \mathrm{PEEK}$ showed better spreading than on pure PEEK. These unique properties of $\mathrm{n}-\mathrm{TiO}_{2}$ significantly

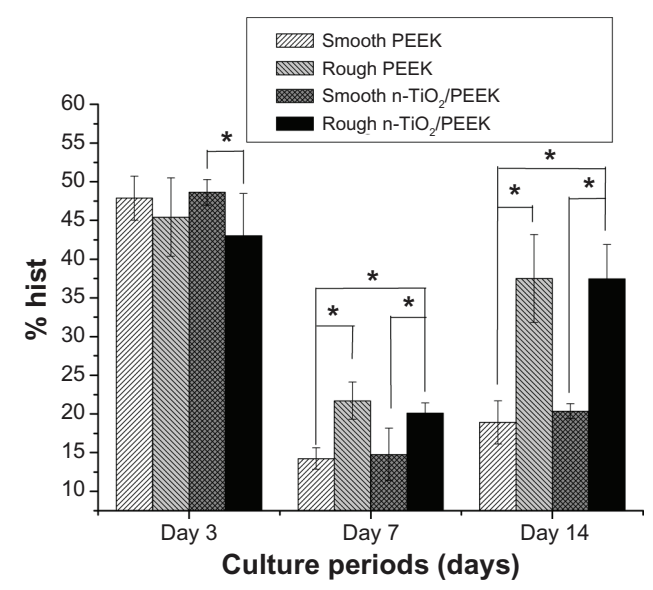

Figure 7 Cell cycle analysis of osteoblasts grown on smooth PEEK, rough PEEK, smooth $\mathrm{n}-\mathrm{TiO}_{2} / \mathrm{PEEK}$, and rough $\mathrm{n}-\mathrm{TiO}_{2} / \mathrm{PEEK}$ for 3,7 , and 14 days.

Note: ${ }^{*} P<0.05$

Abbreviation: PEEK, poly(ether-ether-ketone). enhanced new bone regeneration and bonding to the implants during in vivo testing.

In recent years, $\mathrm{n}-\mathrm{TiO}_{2}$ particles have attracted considerable attention, not only because of their unique physicochemical properties, especially in biomedical applications, but also because of their inflammatory, proliferative, cytotoxic, and

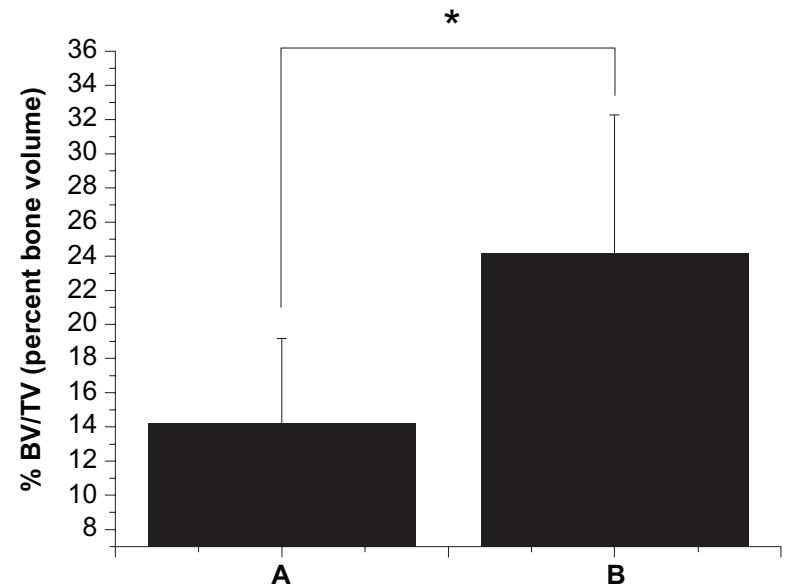

Figure $8 \mathrm{BV} / \mathrm{TV}$ of PEEK (A) and $\mathrm{n}-\mathrm{TiO}_{2} / \mathrm{PEEK}$ (B) was calculated after microcomputed tomography.

Note: $* P<0.05$.

Abbreviations: BV/TV, percent bone volume; PEEK, poly(ether-ether-ketone). 


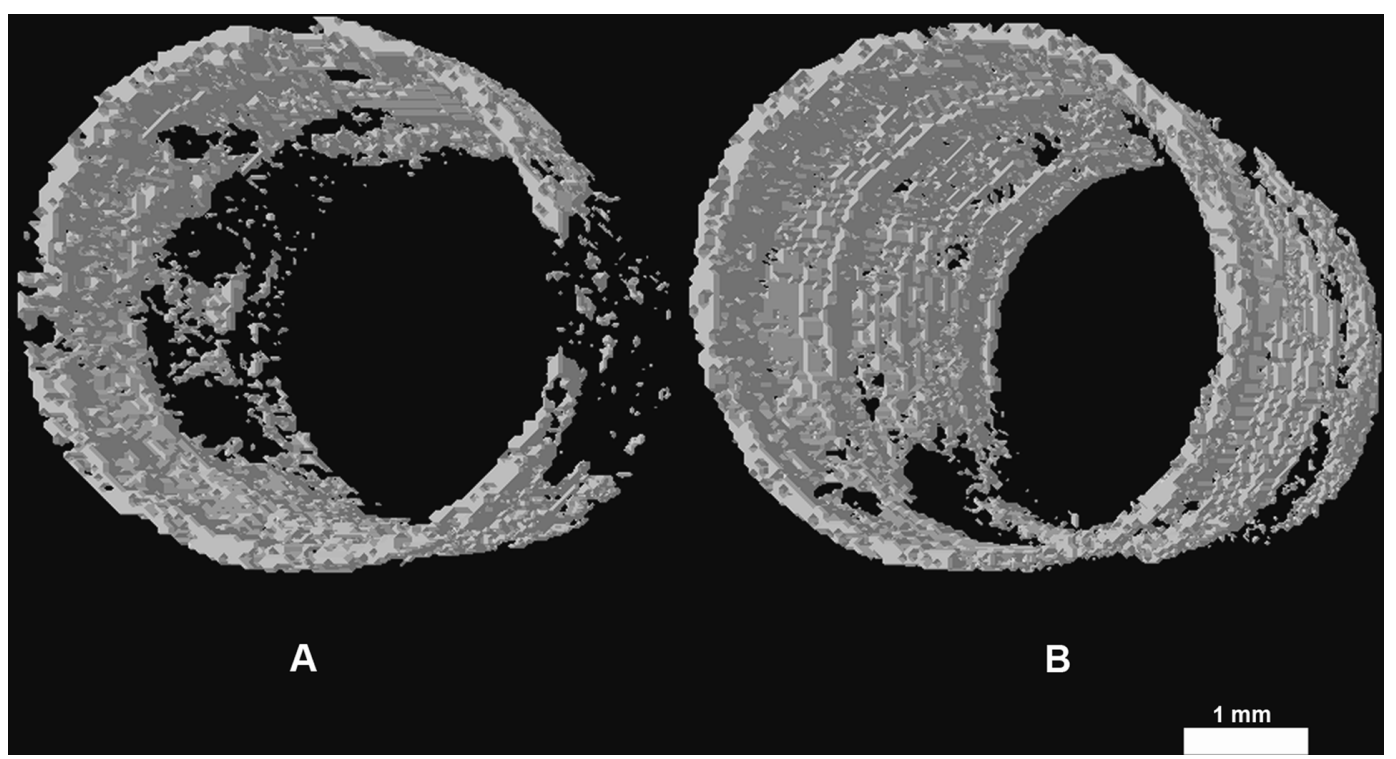

Figure 9 Three-dimensional images showing regeneration of microstructures about $0.5 \mathrm{~mm}$ in thickness bonding to PEEK $(\mathbf{A})$ and $\mathrm{n}-\mathrm{TiO} / \mathrm{PEEK}(\mathbf{B})$ implants in the marrow. Abbreviation: PEEK, poly(ether-ether-ketone).

genotoxic effects. The chemistry and surface morphologic effect of the $\mathrm{n}-\mathrm{TiO}_{2}$ nanostructure also significantly enhanced the proliferation and differentiation of osteoblasts. ${ }^{1,21,22}$ A superthin $(300 \mathrm{pm}-6.3 \mathrm{~nm}) \mathrm{TiO}_{2}$ coating fabricated by slow sputter deposition of molten $\mathrm{TiO}_{2}$ nanoparticles is sufficient to enhance biologic properties of microroughened titanium significantly, and at this thickness range it does not alter the previously created microtopography of the titanium surface. ${ }^{1}$ On the other hand, some reports have shown that various cultured cell models show cytotoxicity when cultured with different doses of free $\mathrm{TiO}_{2}$ nanoparticles, ${ }^{23-25}$ and animal models have show an inflammatory response and tumorigenesis when exposed to free $\mathrm{TiO}_{2}$ nanoparticles. ${ }^{23,26,27}$ Free $\mathrm{TiO}_{2}$ nanoparticles induce rapid phosphorylation in polymorphonuclear neutrophils, with a great potential to induce apoptosis. ${ }^{24}$

Considering the aforementioned studies, we believe that the excellent biocompatibility of $\mathrm{n}-\mathrm{TiO}_{2}$ nanocomposites is mainly due to their exceptional bioactivity and the surface morphologic effects of the $\mathrm{TiO}_{2}$ layer. Cytotoxicity, inflammatory response, or tumorigenesis are due to free $\mathrm{TiO}_{2}$ nanoparticles which could break into the intracellular environment ${ }^{23}$ and tissues from culture media or by administration via nasal administration, oral administration, or instillation. ${ }^{26,27}$ It is important to utilize the chemistry and surface morphologic effect of $\mathrm{n}-\mathrm{TiO}_{2}$ and to limit free n- $\mathrm{TiO}_{2}$ particles when these particles are used to fabricate biomedical materials, especially orthopedic and dental implant materials.
In this study, a n- $\mathrm{TiO}_{2} / \mathrm{PEEK}$ composite was fabricated successfully. $\mathrm{n}-\mathrm{TiO}_{2}$ could be visualized on the surface of $\mathrm{n}-\mathrm{TiO}_{2} / \mathrm{PEEK}$ composites (Figure 2) which showed appropriate homogeneity throughout (Figure 1). Elements of $\mathrm{n}-\mathrm{TiO}_{2}$ were detected on the composite surface by XPS (Figure 3). Therefore, the $\mathrm{n}-\mathrm{TiO}_{2} / \mathrm{PEEK}$ composite could also be considered as a superthin $\mathrm{n}-\mathrm{TiO}_{2}$ layer exposed on the PEEK surface in a safe way such that $\mathrm{n}-\mathrm{TiO}_{2}$ was bound into the PEEK matrix, with only some parts of each nanoparticle exposed to the surface. Several kinds of successfully fabricated PEEK nanocomposites have been reported, such as strontium-containing ( $\mathrm{Sr}$ )-HA/PEEK, nanosized $\mathrm{SiO}_{2} /$ PEEK and nanosized $\mathrm{Al}_{2} \mathrm{O}_{3} / \mathrm{PEEK} .{ }^{20,28}$ When reinforced with 0-30 vol\% Sr-HA, the bending modulus of Sr-HA/PEEK composites increases with the volume ratio of Sr-HA ( $25 \mathrm{vol} \%$, 9.6 GPa; $30 \mathrm{vol} \%, 10.6 \mathrm{GPa}$ ), while the bending strength of the composites decreases with addition of Sr-HA ( $25 \mathrm{vol} \%$, $93.8 \mathrm{MPa} ; 30$ vol $\%$, $89.1 \mathrm{MPa}) .{ }^{20}$ The $25 \mathrm{vol} \% \mathrm{Sr}-\mathrm{HA}$ was chosen to produce the composites for in vitro testing, which was due to the desired mechanical performance. In this study, $40 \mathrm{wt} \% \mathrm{n}-\mathrm{TiO}_{2}$ was chosen to fabricate the $\mathrm{n}-\mathrm{TiO}_{2} / \mathrm{PEEK}$ composite, which was based on an optimization between the bending modulus (3.8 GPa) and bending strength (93 MPa).

In vitro studies showed that $\mathrm{n}-\mathrm{TiO}_{2}$ did not cause severe cytotoxicity or disturb cell cycle progression, but improved the bioactivity of PEEK. Although the rough $\mathrm{n}-\mathrm{TiO}_{2} / \mathrm{PEEK}$ group showed lower cell proliferation and viability (Figure 5) than the other groups, $\mathrm{n}-\mathrm{TiO}_{2}$ did not cause severe cytotoxicity in the $n-\mathrm{TiO}_{2} / \mathrm{PEEK}$ nanocomposite, and the relative 

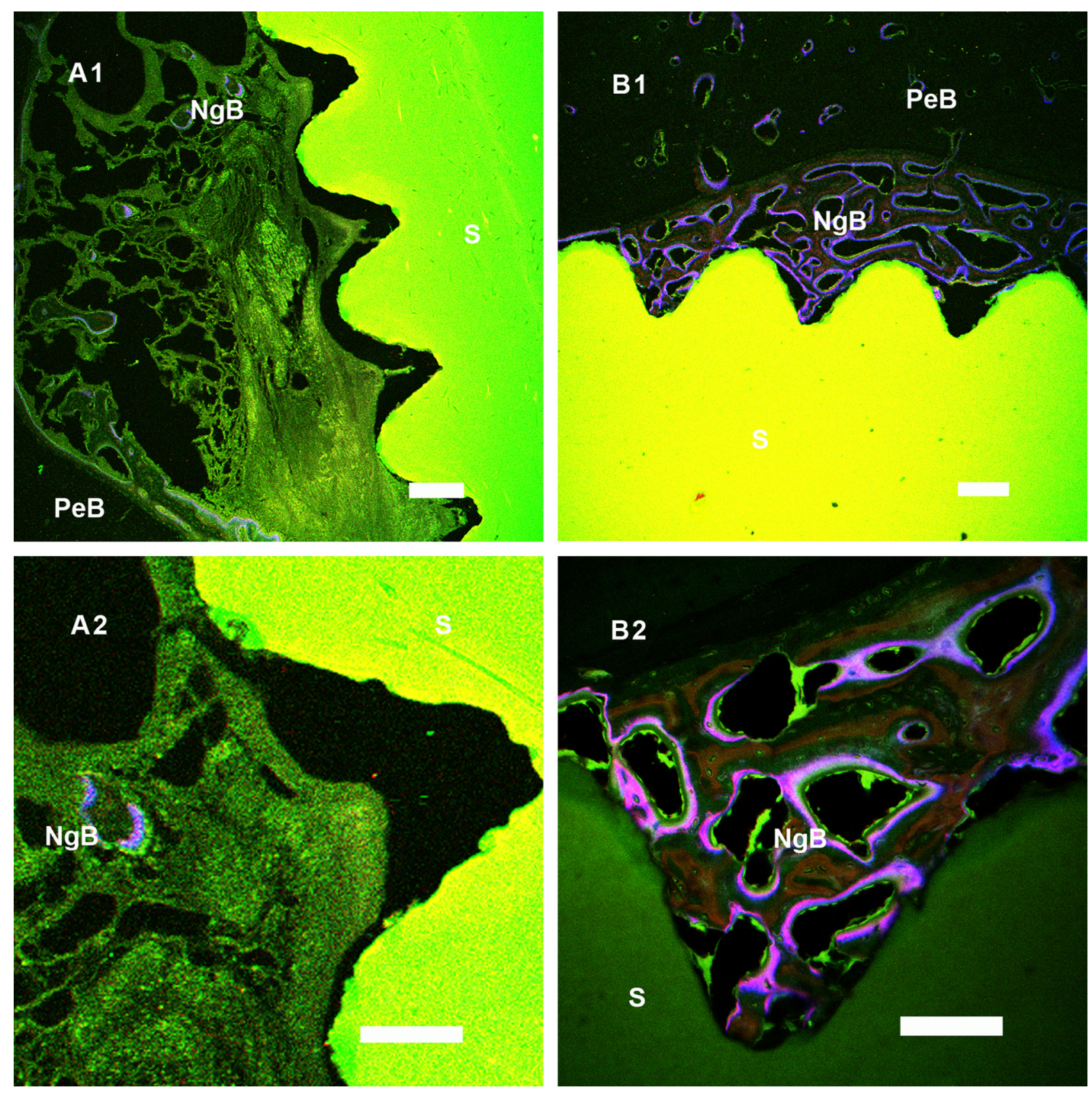

Figure 10 In histological analysis, new bone formation around the PEEK and n-TiO $/$ PEEK were detected by bone labelling (calcein, calcein blue, and tetracycline). Group $\mathrm{A}$ was PEEK and group $\mathrm{B}$ was $\mathrm{n}-\mathrm{TiO}_{2} / \mathrm{PEEK}$. Original magnification of $(\mathbf{A I})$ and $(\mathbf{B I})$ was $5 \times$ and $(\mathbf{A 2})$ and $(\mathbf{B} 2)$ was $20 \times$.

Notes: $\mathrm{A} I$ and $\mathrm{BI}$ bar, $200 \mu \mathrm{m} ; \mathrm{A} 2$ and B2 bar, $100 \mu \mathrm{m}$.

Abbreviations: S, sample; $\mathrm{NgB}$, newly grown bone deposition and remodeling zone; PeB, pre-existing bone tissue zone; PEEK, poly(ether-ether-ketone).

growth rate of the $\mathrm{n}-\mathrm{TiO}_{2} / \mathrm{PEEK}$ composites was more than $80 \%$. Flow cytometric analysis (Figure 7) showed that $\mathrm{n}-\mathrm{TiO}_{2}$ did not disturb cell cycle progression compared with the pure PEEK groups. After long-term culture (for 7 and 14 days), osteoblast cells on both rough PEEK and $\mathrm{n}-\mathrm{TiO}_{2} / \mathrm{PEEK}$ surfaces contained a significantly larger portion in the $\mathrm{S}$ and G2M phases compared with cells on the smooth surface. This suggested that the rough-surfaced PEEK was beneficial to the proliferation of osteoblast cells. Other studies have reported that the rough surface of substrate materials improves proliferation and differentiation of osteoblasts. . $21,29,30^{2}$

Furthermore, in cell attachment testing (Figure 4), $\mathrm{n}-\mathrm{TiO}_{2}$ significantly improved cell attachment to $\mathrm{n}-\mathrm{TiO}_{2} / \mathrm{PEEK}$ compared with pure PEEK. This is consistent with the cell morphology test (Figure 6). Cells on smooth $\mathrm{n}-\mathrm{TiO}_{2} / \mathrm{PEEK}$ appeared better spread, with numerous pseudopods. The pseudopods of osteoblasts on the smooth $\mathrm{n}-\mathrm{TiO}_{2} / \mathrm{PEEK}$ disks seemed to anchor exposed n- $\mathrm{TiO}_{2}$ particles to the surface of the composite and formed a superthin coating on the PEEK surface, indicating that the surface morphologic effect of $\mathrm{n}-\mathrm{TiO}_{2}$ promotes the bioactivity of $\mathrm{n}-\mathrm{TiO}_{2} / \mathrm{PEEK}$. A similar effect was observed in other studies using $\mathrm{n}-\mathrm{TiO}_{2} \cdot \mathrm{An} \mathrm{n}-\mathrm{TiO}_{2}$ superthin coated Ti surface significantly improves osteoblast cell attachment. ${ }^{1}$ Ti coating on PEEK also enhances cell attachment, proliferation, and differentiation of osteoblasts. ${ }^{7}$ All of these studies suggest that the chemistry and surface morphologic effect of $\mathrm{n}-\mathrm{TiO}_{2}$ particles plays an important role in the exceptional bioactivity of $\mathrm{n}-\mathrm{TiO}_{2}$. 
Our in vitro test results were consistent with those of in vivo testing. Microcomputed tomography is effective and reproducible for monitoring tumor-associated bone destruction, ${ }^{31,32}$ analyzing the three-dimensional structure of scaffolds, ${ }^{33}$ measuring subtle differences in bone growth into three-dimensional scaffolds, and calculating new bone deposition around implants. ${ }^{34,35}$ In this study, the percent of bone volume/tissue volume of regenerated bone in the marrow bonding to the implants was calculated, and three-dimensional images were constructed. n-TiO $2 / \mathrm{PEEK}$ showed higher bone volume/tissue volume than pure PEEK (Figure 8). Three-dimensional (Figure 9) and histologic images (Figure 10) showed the same results, suggesting that $\mathrm{n}-\mathrm{TiO}_{2}$ enhances the bioactivity of $\mathrm{n}-\mathrm{TiO}_{2} / \mathrm{PEEK}$. In terms of the potential risks of free $n-\mathrm{TiO}_{2}$ particles, the novel bioactivity of $\mathrm{n}-\mathrm{TiO}_{2}$, such as chemistry and surface morphologic effect, is still attractive. It is important to utilize its outstanding bioactive properties and limit free $n-\mathrm{TiO}_{2}$ when it is used in biomaterials, especially orthopedic and dental implants.

\section{Conclusion}

In this study, $\mathrm{n}-\mathrm{TiO}_{2} / \mathrm{PEEK}$ composites were fabricated and their in vitro and in vivo bioactivity was assessed. In in vitro testing, instead of causing cytotoxicity or disturbing cell cycle progression, $\mathrm{n}-\mathrm{TiO}_{2}$ improved the bioactivity of PEEK. It promoted cell attachment and improved osteoblast cell spreading. In the in vivo studies, enhanced bone regeneration around the implants by $n-\mathrm{TiO}_{2}$ was indicated by higher bone volume/tissue volume and vivid visualization in three-dimensional and histologic images.

A special effect of $n-\mathrm{TiO}_{2}$ on the composite surface was also observed. Bioactivity evaluation of the nanocomposites revealed that pseudopods of osteoblasts preferred to anchor at areas where $n-\mathrm{TiO}_{2}$ presented at the surface. This study also showed that the surface roughness of $n-\mathrm{TiO}_{2} / \mathrm{PEEK}$ composites played a prominent role in promoting cell attachment and regeneration of new bones. Our study suggests that $\mathrm{n}-\mathrm{TiO}_{2} / \mathrm{PEEK}$ composites utilize the attractive bioactivity of $\mathrm{n}-\mathrm{TiO}_{2}$ as well as the outstanding mechanical properties of PEEK, and could be a potential substitute for metal implant material in orthopedic and dental applications.

\section{Acknowledgments}

This work was supported by the State Key Development Program for Basic Research of China (grant 2007CB936103), the Fundamental Research Funds for the Central Universities and Peking University 985 Grant, Nanospecial Program of Science and Technology Development of Shanghai (1052nm06600), and Key Medical Program of Science and Technology Development of Shanghai (09411954900). The authors express appreciation to Dr Dongsheng Wang (Institute of Stomatology, Chinese PLA General Hospital) for his technical assistance in histologic analysis. The authors also thank Xiaohong $\mathrm{Wu}$ for assistance in microcomputed tomography analysis, Feilong Nie for assistance with the animal experiments, and Qiuhong Li for assistance with the cell experiments.

\section{Disclosure}

The authors report no conflicts of interest in this work.

\section{References}

1. Sugita Y, Ishizaki K, Iwasa F, et al. Effects of pico-to-nanometer-thin $\mathrm{TiO} 2$ coating on the biological properties of microroughened titanium. Biomaterials. 2011;32(33):8374-8384.

2. Taxt-Lamolle SF, Rubert M, Haugen HJ, Lyngstadaas SP, Ellingsen JE, Monjo M. Controlled electro-implementation of fluoride in titanium implant surfaces enhances cortical bone formation and mineralization. Acta Biomater. 2010;6(3):1025-1032.

3. Rausch-fan X, Qu Z, Wieland M, Matejka M, Schedle A. Differentiation and cytokine synthesis of human alveolar osteoblasts compared to osteoblast-like cells (MG63) in response to titanium surfaces. Dent Mater. 2008;24(1):102-110.

4. Buly RL, Huo MH, Salvati E, Brien W, Bansal M. Titanium wear debris in failed cemented total hip arthroplasty: An analysis of 71 cases. J Arthroplasty. 1992;7(3):315-323.

5. Stadelmann VA, Terrier A, Pioletti DP. Microstimulation at the boneimplant interface upregulates osteoclast activation pathways. Bone. 2008;42(2):358-364.

6. Ramakrishna S, Mayer J, Wintermantel E, Leong KW. Biomedical applications of polymer-composite materials: a review. Compos Sci Technol. 2001;61(9):1189-1224.

7. Han CM, Lee EJ, Kim HE, et al. The electron beam deposition of titanium on polyetheretherketone (PEEK) and the resulting enhanced biological properties. Biomaterials. 2010;31(13):3465-3470.

8. Wong KL, Wong CT, Liu WC, et al. Mechanical properties and in vitro response of strontium-containing hydroxyapatite/polyetheretherketone composites. Biomaterials. 2009;30(23-24):3810-3817.

9. Kurtz SM, Devine JN. PEEK biomaterials in trauma, orthopedic, and spinal implants. Biomaterials. 2007;28(32):4845-4869.

10. Chiang CY, Chiou SH, Yang WE, et al. Formation of $\mathrm{TiO}_{2}$ nano-network on titanium surface increases the human cell growth. Dent Mater. 2009;25(8):1022-1029.

11. Long M, Rack HJ. Titanium alloys in total joint replacement-a materials science perspective. Biomaterials. 1998;19(18):1621-1639.

12. Wu LN, Genge BR, Wuthier RE. Micropatterned $\mathrm{TiO}_{2}$ effects on calcium phosphate mineralization. Mater Sci Eng C. 2009;29(8):2355-2359.

13. Tsou H-K, Hsieh P-Y, Chung C-J, Tang C-H, Shyr T-W, He J-L. Low-temperature deposition of anatase $\mathrm{TiO}_{2}$ on medical grade polyetheretherketone to assist osseous integration. Surf Coat Technol. 2009;204(6-7):1121-1125.

14. Gutwein LG, Webster TJ. Osteoblast and chondrocyte proliferation in the presence of alumina and titania nanoparticles. J Nanopart Res. 2002;4(3):231-238.

15. Kubo K, Tsukimura N, Iwasa F, et al. Cellular behavior on TiO2 nanonodular structures in a micro-to-nanoscale hierarchy model. Biomaterials. 2009;30(29):5319-5329.

16. Brammer KS, Oh S, Cobb CJ, Bjursten LM, van der Heyde H, Jin S. Improved bone-forming functionality on diameter-controlled $\mathrm{TiO}_{2}$ nanotube surface. Acta Biomater. 2009;5(8):3215-3223. 
17. Lu X, Lv X, Sun Z, Zheng Y. Nanocomposites of poly(l-lactide) and surface-grafted TiO2 nanoparticles: Synthesis and characterization. Eur Polym J. 2008;44(8):2476-2481.

18. Torres FG, Nazhat SN, Fadzullah SH, Maquet V, Boccaccini AR. Mechanical properties and bioactivity of porous $\mathrm{PLGA} / \mathrm{TiO}_{2}$ nanoparticle-filled composites for tissue engineering scaffolds. Compos Sci Technol. 2007;67(6):1139-1147.

19. Wei J, Chen QZ, Stevens MM, Roether JA, Boccaccini AR. Biocompatibility and bioactivity of PDLLA/TiO2 and PDLLA/TiO2/ Bioglass $^{\circledR}$ nanocomposites. Mat Sci Eng C. 2008;28(1):1-10.

20. Wong KL, Wong CT, Liu WC, et al. Mechanical properties and in vitro response of strontium-containing hydroxyapatite/polyether ether ketone composites. Biomaterials. 2009;30(23-24):3810-3817.

21. Gittens RA, McLachlan T, Olivares-Navarrete R, et al. The effects of combined micron-/submicron-scale surface roughness and nanoscale features on cell proliferation and differentiation. Biomaterials. 2011;32(13):3395-3403.

22. Wang N, Li H, Lü W, et al. Effects of $\mathrm{TiO}_{2}$ nanotubes with different diameters on gene expression and osseointegration of implants in minipigs. Biomaterials. 2011;32(29):6900-6911.

23. Huang S, Chueh PJ, Lin YW, Shih TS, Chuang SM. Disturbed mitotic progression and genome segregation are involved in cell transformation mediated by nano-TiO 2 long-term exposure. Toxicol Appl Pharmacol. 2009;241(2):182-194.

24. Gonçalves DM, Chiasson S, Girard D. Activation of human neutrophils by titanium dioxide $\left(\mathrm{TiO}_{2}\right)$ nanoparticles. Toxicol In Vitro. 2010;24(3):1002-1008.

25. Boccaccini AR, Gerhardt LC, Rebeling S, Blaker JJ. Fabrication, characterisation and assessment of bioactivity of poly(D, L lactic acid) (PDLLA) $/ \mathrm{TiO}_{2}$ nanocomposite films. Composites Part A. 2005;36(6): 721-727.

26. Wang J, Liu Y, Jiao F, et al. Time-dependent translocation and potential impairment on central nervous system by intranasally instilled $\mathrm{TiO} 2$ nanoparticles. Toxicology. 2008;254(1-2):82-90.
27. Wang Y, Wertheim DF, Jones AS, Coombes AG. Micro-CT in drug delivery. Eur J Pharm Biopharm. 2000;74(1):41-49.

28. Kuo MC, Tsai CM, Huang JC, Chen M. PEEK composites reinforced by nano-sized $\mathrm{SiO}_{2}$ and $\mathrm{Al}_{2} \mathrm{O}_{3}$ particulates. Mater Chem Phys. 2005;90(1): 185-195.

29. Pegueroles M, Aparicio C, Bosio M, et al. Spatial organization of osteoblast fibronectin matrix on titanium surfaces: Effects of roughness, chemical heterogeneity and surface energy. Acta Biomater. 2010;6(1): 291-301.

30. Zhao G, Raines AL, Wieland M, Schwartz Z, Boyan BD. Requirement for both micron- and submicron scale structure for synergistic responses of osteoblasts to substrate surface energy and topography. Biomaterials. 2007;28(18):2821-2829.

31. Johnson LC, Johnson RW, Munoz SA, Mundy GR, Peterson TE, Sterling JA. Longitudinal live animal micro-CT allows for quantitative analysis of tumor-induced bone destruction. Bone. 2011;48(1):141-151.

32. Samei E, Saunders RS, Badea CT, et al. Micro-CT imaging of breast tumors in rodents using a liposomal, nanoparticle contrast agent. Int $J$ Nanomedicine. 2009;4(1):277-282.

33. Jones AC, Arns CH, Sheppard AP, Hutmacher DW, Milthorpe BK, Knackstedt MA. Assessment of bone ingrowth into porous biomaterials using Micro-CT. Biomaterials. 2007;28(15):2491-2504.

34. Alt V, Lips KS, Henkenbehrens C, et al. A new animal model for implant-related infected non-unions after intramedullary fixation of the tibia in rats with fluorescent in situ hybridization of bacteria in bone infection. Bone. 2011;48(5):1146-1153.

35. Zhou W, Han C, Song Y, et al. The performance of bone marrow mesenchymal stem cell-implant complexes prepared by cell sheet engineering techniques. Biomaterials. 2010;31(12):3212-3221.
International Journal of Nanomedicine

\section{Publish your work in this journal}

The International Journal of Nanomedicine is an international, peerreviewed journal focusing on the application of nanotechnology in diagnostics, therapeutics, and drug delivery systems throughou the biomedical field. This journal is indexed on PubMed Central,

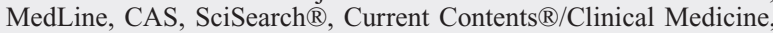

\section{Dovepress}

Journal Citation Reports/Science Edition, EMBase, Scopus and the Elsevier Bibliographic databases. The manuscript management system is completely online and includes a very quick and fair peer-review system, which is all easy to use. Visit http://www.dovepress.com/ testimonials.php to read real quotes from published authors. 